\title{
Assessing the Storage Potential of Some Vegetable Products in Some Selected Areas in Kano State
}

\author{
${ }^{1}$ Awagu, E. F., ${ }^{2}$ Adedayo M. R., ${ }^{3}$ Olayemi F.F. \\ ${ }^{I}$ Nigerian Stored Products Research Institute, P.M.B.3032, Hadejia Road, Kano, NIGERIA \\ ${ }^{2}$ Microbiology unit, Department of Biosciences and Biotechnology, College of Pure and Applied Sciences, \\ Kwara State University, Malete, PMB 1530, Malete, Nigeria. \\ ${ }^{3}$ Nigerian Stored Products Research Institute, Ilorin, Kwara State, Nigeria
}

\begin{abstract}
A total of 112 questionnaires were randomly distributed among fruits and vegetable producers of Gazawa, Garum-mallam and Kura Local Government Areas of Kano State Nigeria. Information were obtained on the farmers storage potential of fruits and vegetables such as stages and time of harvest, harvesting and processing methods, transportation, storage conditions, packaging and storage. The bulk of farmers were made up of fairly young people. Most of the farming operations were done manually with tomato and onions produced majorly. They had highest farm capacity of 5 hectares without specified stage and time of harvest. Products were majorly sold immediately after harvest with poor processing, packaging, transporting and storage systems. Results of the survey was analyzed and presented in percentages. Obviously this project has discovered there is gross inadequacy in harvesting, handling, processing techques, storage structure for vegetable products among the farmers which therefore means low storage know- how as it was revealed by their response. Conclusively, the farmers lack general knowledge in storage technology, properly due lack of farming experience, therefore these could be responsible for the huge losses of fruits and vegetables in Kano state and the country at large. Intensified enlightenment by concerned bodies like NSPRI, ADP, and KNADA was recommended.
\end{abstract}

Keywords: Fruits, Vegetables, Farmers, storage potential, Gazawa, Garum-mallam and Kura

\section{Introduction}

The health benefits of a diet rich in vegetables and fruits cannot be over emphasized; they include, lower blood pressure; reduced risk of heart disease, stroke, and probably some cancers; lower risk of eye and digestive problems; and a mellowing effect on blood sugar that can help keep appetite in check. Vegetable, the edible product of an herbaceous plant - that is, a plant with a soft stem, as distinguished from the edible nuts and fruits produced by plants with woody stems such as shrubs and trees. Vegetables can be grouped according to the edible part of each plant: leaves (lettuce), stalks (celery), roots (carrot), tubers (potato), bulbs (onion), and flowers (broccoli). In addition, fruits such as the tomato and seeds such as the pea are commonly considered vegetables. Most vegetables are valuable sources of vitamins, minerals, and fiber and are low in fat and calories (Decuypere, 2000, Harvard and Smith 1994).

Fresh fruits and vegetables are however difficult to store, they are categorized under the perishable crops naturally rich in juices and sugar and are slightly acidic. These components induce growth of yeast and bacteria which are the organisms causing deterioration in these crops (Edward, 1998 and Smith, A.F.1994). A conservative estimate has put the wastages in Nigeria at about 60-70 \% of harvested vegetables and fruits (Tindall and proctor 1980). Kano state produces large quantity of vegetables, however due to the prevalence of harvesting and post-harvest deterioration, a large portion of it is lost. Deterioration of vegetables, manifest itself as damages which may be mechanical, physical, physiological, biochemical or pathological. These damages usually may be associated with poor handling during harvesting, packaging, transporting, storage and marketing. The prevalent hot climate in Kano further aids the rate of spoilage which is against one of the characteristics of vegetables in that they store better under low temperature condition.

Many vegetables and fruits are seasonal in production, their availability may be limited to specific periods, and for some it may be possible to produce them during a limited season. In general, there are seasonal surpluses and losses which can only be reduced by adopting storage techniques, the shelf life of perishables ranging from a few days to a few weeks (Okanlawon, 1999).This study is therefore aimed at assessing the storage potentials of vegetable farmers in Kano state to enhance all year round availability and reduce wastage.

\section{Materials And Methods}

The study was conducted between January and March of the year when the farmers were carrying out irrigation farming of fruits and vegetables. A preliminary survey was carried out to identify the major fruits and vegetables produce in the State. The survey was conducted in three Local Government Areas of Kano state, Gazawa, Garum-mallam and Kura Local Government Areas. Kano State has arable non marshy vegetation well- 
drained, none highly acidic fluvisol. The total annual rainfall is about $228 \mathrm{~mm}$ and temperature ranges from 29 to $38.2^{\circ} \mathrm{C}$ in the dry season, mean monthly Sunshine hours 2,957.1 ( Hong Kong, 2012)

A total of one hundred and twelve farmers were randomly selected with the help of the Community Development Co-coordinating committee of the communities. They are specifically, Okra, Tomatoes, Onions, Pepper, Rice, Maize, Cucumber and Pumpkin farmers with years of experience. The survey was conducted using the method of Investigative Survey Research Approach (ISRA) (Anazodo et al., 1986). Information was collected using structured questionnaire which sought for the following information: personal information like age, family size, years of experience and level of education, the periods, crop storage awareness, structures used and for how long, loss during storage and processing method and degree of post harvest losses of agricultural produce.

The study also took some personal observation to get salient information that would help identify problems faced by the farmers. After the interview, the data were manually collated and analyzed by finding the frequencies of each response and expressed as a percentage of the entire respondent

\section{Result And Discussion}

A total of one hundred and Twelve questionnaires were administered in selected areas in Kano state where vegetables especially tomatoes and onions are commonly produced. The selected areas are in Gazawa, Garun-mallam and Kura Local Government Areas. The result indicated (fig.1) that the bulk of vegetable farmers in the study areas are within the ages of 30- 39 years making up 34\% of the respondents followed by 20-29 years constituting $23 \%, 20 \%$ falls within $40-49$ years of age, $14 \%$ are between $50-59$ years old $7 \%$ are between 60-69 years old while $2 \%$ are within 70 years and above. This is an indication that fairly young people are involved in this kind of business compared to the elderly ones who may not have the physical strength require as result of old age. It may also be an indication that the venture is lucrative for it to attract the attention of young men. The youth acknowledged that without agriculture there would be no food. If agriculture disappeared, their personal lives, as well as the community and state, would be affected (Krueger, R.A. 1988). Vegetable farming in Kano state is gender specific as $100 \%$ of the respondent are men this is traceable to the religion and cultural background of the people of the Northern states. (Lale and Okunade 1998). It was discovered that $46 \%$ of the respondents carry out their farming operations manually, 33\% used machines for land cultivation but carry out other operations on the farm manually, while $21 \%$ were fully practicing mechanized farming except for harvesting which they claim to be doing manually(fig.2). The youth indicated a belief that people get into agriculture because they grew up on the farm. Most of them did not think someone could farm, just because he or she wanted to. They felt buying land, machinery, etc, would be too expensive unless someone had received help to get started (Krueger, R.A. 1988). A total of 55.3\% of the respondents had above ten years experience in vegetable farming, $28.5 \%$ had 6-10 years while the remaining,16.2\%, had 1-5 years of experience(fig.3).This may be explained by the fact that the majority of the people involved in this business were fairly young people. The farmers' level of experience shown that they were not vast in the system (Olayemi F. F. et al 2010), the elderly ones do not stay long on farming, properly they abandon it for other works due to lack of adequate information on farm practices. Poor management and inadequate knowledge of good farming practices have been known to affect post harvest quality of fruits and vegetables especially tomatoes with high moisture content adversely (Agboola, 1980). Tomato and Onion are important commodities for the preparation of many local dishes in Nigeria, they play major role in providing vitamins and minerals for humans (Smith, 1994). This implies that Tomato and Onion are very important vegetable in the study area. The pattern of land allocation observed may not be unconnected to the returns /earnings from the respective vegetable enterprises. (Ibrahim H.K.2011) (fig.4), closely followed by pepper while other vegetable crops are minor. The respondents produced tomato and onions (70\%) majorly, while other crops were minor. On the other hand, 10\% produce onion majorly, only $9 \%$ of the respondents claimed that pepper was the major crop they produce. Others produced rice and maize $(2 \%)$ together with other crops on their farm. Tomato produce singularly was $6 \%$, while mixed produce of tomatoes, onions and pepper was $3 \%$ (fig.4). The higher energy output-input ratio for tomato and onion production indicated a higher yield per hectare from the other crops. A total of $71 \%$ of the respondents have their farm capacity ranging between 1-2 hectares of land, 19.6\% use 3-5 hectares of land for farming, 3.5\% used above 5 hectares of land while $5.9 \%$ used below one hectare of land for their farming work (fig.5). This may be due to the fact that the majority of the respondents were not on mechanized farming as a result of which they could not put much land into use, again it may be that there were no means of storing their produce in case of excess production (Tindall and Proctor ,1980).

It was observed that respondents were majorly commercial farmers producing large quantities of vegetables for sale within and outside the state. $91 \%$ of the farmers are commercial vegetable farmers while only $9 \%$ were subsistence (fig; 6), producing only a little quantity for sale. Selling direct to the consumer such as a road side stall or farmers market has the lowest costs and lowest number of constrains. Glutting of produce in the markets can be prevented if the farmers are able to store their produce for later markets and only products of high initial quality can be stored successfully (Muhammad,R.H.2012).Almost all of them became commercial 
farmers compulsorily because they do not know how to keep their products for longer period of time. The method of harvesting vegetable used by these farmers was the hand or manual method. Vegetable crops however, may be harvested mechanically, if a hardy variety or if not intended for the fresh market. Many fruits and vegetables, especially citrus fruits, are harvested almost exclusively by hand because they must arrive on the fresh market in perfect condition, and mechanical harvesting can scratch or bruise produce. Damage is a major concern of reap harvesting, only the few farmers producing rice and maize said they were making use of machines for harvesting their products. Grain crops are harvested mechanically because they are hardy and cannot be easily scratched or bruise. Thus $98.1 \%$ harvests their products with hand while only $1.9 \%$ uses machines for harvesting. This is because the production is mainly for the house hold not exportation (fig.7). The total yield per annum of these vegetables is not well quantified because the farmers do not have proper records of their yearly production due to the level of education and poor technical know-how. However from the information gathered from the respondents, the farmers produce about 250,000 tones of tomatoes (33\%), 300,000 tones of onions (39\%) 150,000 tones of pepper (20\%), 10 tons of rice (1\%) and about 50,000 tons of maize (7\%) per annum (fig.8). The stage of harvest of these vegetables is very important in determining their self life. A total of $81.5 \%$ of the farmers harvest their tomatoes and pepper when it is red ripe, $10.7 \%$ harvest their own at the matured green stage, while $7.8 \%$ harvest a mixture of red ripe, matured green and just ripe stages(fig.9). Tomatoes and pepper harvested at the red ripe stage get spoil easily and quickly during transportation before reaching the consumers and thus become wasted or are sold at a very cheap rate. Some fruits and vegetables like tomatoes are best harvested when fully matured and still in the green stage, matured tomatoes stays longer as they ripen gradually while tomatoes that are already ripe will have a short storage life. Harvesting of onion is usually done when the tip of the leaves have started drying. Another factor that also determines the shelf life of these vegetables is the time of the day when harvesting is done, vegetable crops harvested in the afternoon under the hot sunshine absorb a lot of field heat that predisposes it to spoilage.(Tindall andProctor.,1980).A total of $92.8 \%$ of the respondents harvest their crops early in the morning between six and ten o'clock before the sun becomes too hot $1.7 \%$ carry out harvesting in the afternoon, $1.7 \%$ harvest their produce late in the evening when the sun has gone down while $3.8 \%$ said they do their own harvesting at any time of the day( Fig. 10). Harvest should be completed during the coolest time of the day (at about $20^{\circ} \mathrm{C}$ ) which is usually in the early morning or evening and should be kept shaded in the field to remove field heat (Mary, 1997). When asked about the problems they usually encounter during harvesting ,75\% said they do not usually have problem with their harvesting, $19.7 \%$ said the only problems they encounter is the problem of insufficient labor while others , 5.3\% said they usually encounter the problem of rottenness or insect attack during harvesting(fig.11). These problems usually result in low yield and poor harvest for the farmers. Tomatoes are susceptible to eelworm attack which further predisposes them to rottenness right from the field (Denton), also insects such as heliothis spp a fruit borer, aphids, and white fly has been reported to cause considerable damages in tomato farms and their effect could be most serious in the dry season when irrigational farming of these vegetables are commonly carry out. The respondents are ready to sell their products immediately where there is ready market or ready buyers for their products. $97.3 \%$ sells the product immediately while $2.7 \%$ sells their products immediately only occasionally, but not always, as they may not get ready buyer (fig.12). Majority of these farmers, about $67.8 \%$ take their products to the market for sale, $17.8 \%$ sells their products either on the farm or take it to the market for sale while, $7.1 \%$ sell their products on the farm to middle-men who carry them to other states for sale and $4.4 \%$ sells their products in their houses (fig.13). Farmers' markets can offer farmers increased profit over selling to wholesalers or food processors, by selling directly to consumers, produce often needs: less transport, less handling, less refrigeration, less time in storage. By selling in an outdoor market, the cost of land, buildings, lighting and air-conditioning is also reduced or eliminated.The location of the farms were not very close to the market and this affect the proximity of the farmers to the markets where they sell their products.62.5\% of the respondents have their farms above $10 \mathrm{~km}$ away from the market, $3.5 \%$ have their farms located at above $5 \mathrm{~km}$ away from the market, $19.6 \%$ have their farm locations between $3-5 \mathrm{~km}$ away from the market, while $14.4 \%$ have their farm locations between $1-3 \mathrm{~km}$ away from the nearest market (fig.14). This will bring increase in the cost of farm products also degradation due to distance coverage to the market and environmental conditions. Most of the mechanical damage to fresh tomatoes and peppers results from the vibrations and impacts received by the produce (Singh and Singh 1992), these vibrations is as a result of the irregularities of the road surfaces which are transmitted through the suspension systems of the vehicles to the produce. Also the use of good packaging material that will not restrict ventilation, will not allow the produce to rest directly on each other and will be easy to carry should be adopted for use (Mary, 1997). A total of $60.7 \%$ of this respondents claims they have easy access to the market as they go to the market by bus, cars, motorcycles or bicycles.32.1\% said they have problem getting to the market because they do not have their own vehicles and also the do not have direct access to public or commercial vehicles the remaining $7.3 \%$ are indifferent on the problem of transporting their products to the market (Fig. 15). Market accessibility has a lot to do in determining the marketability of these vegetables. When the farmers could not get their products to the market on time, spoilage sets in thus reducing the market value of the products. In some 
cases they become so bad that they have to be discarded. A key factor in establishing commercial vegetable production is access to markets. There is little point in developing a vegetable production operation unless there is a means of physically getting the product to market. Whatever transport used, be it by bicycle, cart, boat, or 'on hoof', it must be adequate in upholding the quality of vegetables (FAO). During the dry season, the farmers carry out irrigation farming of these vegetables, at this time the yield is mostly very high and there are usually surpluses. The surpluses, in most cases are not stored by reason of ignorance then allowed to waste away through deterioration by various agents. Again, poor management and inadequate knowledge of good farming practices have been known to affect post harvest quality of fruits and vegetables especially tomatoes with high moisture content adversely (Agboola, 1980). Most vegetables require low temperatures and high humidity, two factors that don't come together easily (Janet and Richard, 2000). A total of 75\% of the respondents said; when they have excess production which they could not sell immediately, essentially for tomatoes, they slice them and dry. The drying is usually done along the highway thereby making the products un-hygienic and less attractive as a result of dust and other contaminants. This leads to drastic reduction in price and consequently in the income of the farmers compare to the price and income if the tomatoes were still fresh. (Tindall and Proctor, 1980 and Okanlawon, 1999). Primary processing is the conversion of an unstable perishable produce into stable long lasting one like the dehydrating of bell and hot pepper or the production of tomato paste, puree, tomapep e.t.c. Vegetables destined for processing and storage should be as free as possible from skin breaks, bruises, spots, rots, decay, and other forms of deterioration ( Mary,1997). The sliced samples are spread out in single layer on mats, surface of rocks, mud roofs and on road sides and exposed to environmental effects. It takes 13 days and 8 days in high humid and low humid weather respectively to dry tomatoes in open sun. Considerable percentage of up to 30 to $50 \%$ of the drying tomatoes deteriorates due to slow rate of drying (Eke, 2010) About $10 \%$ of the farmers said they sell cheaply, $3 \%$ said they use it at home, $2 \%$ use it as gift to the less privileged while 10\% said it gets rotten and wasted. (Fig: 16) From the above data it is obvious that the farmers have no means of preserving or storing their tomatoes after harvesting in order to increase its self life, ensure availability and forestall unreasonable increase in price all year round. The losses of over $50 \%$ experienced by the majority of the farmers may be attributed to their use of local baskets in packaging of their produce after harvest, the basket are rough and easily bruises the produce and poorly ventilated, hence rot sets in. The use of a clean smooth and well-ventilated container (wooden or plastic crates) is a very important factor in cutting down losses in produce during harvesting, transportation, marketing and storage (NSPRI, 1991). As seen (fig. 6) onion which is of lower moisture content than tomato is stored or preserved although not in a proper store. Thus the crop is still been exposed to spoilage through agent of heat, moisture, insects and microorganisms. The major means of storage according to the finding of this research is locally constructed shed from grass and other agricultural waste which usually been erected in open places on the farm, about $50 \%$ of the farmers store their onions in this kind of structure. $20 \%, 15 \%, 8 \%$ and $7 \%$ of the farmers, store their onions in a mini store, a room in their house where the onions are just spread on the bare floor, jute bags and polythene bags respectively (fig.17). These bags are now stacked directly on each other in a room. This problem of inadequate means of storage goes a long way to affect the quality and quantity of vegetable crops that these farmers are able to store as a result of which there is a lot of wastage and invariably scarcity and loss of income to the farmers. For optimum storage quality, onions must be cured soon after harvest. Optimum conditions are $68-86^{\circ} \mathrm{F}$ and $70 \%$ relative humidity for at least 12 to $24 \mathrm{~h}$. Curing decreases the incidence of neck rot, reduces water loss during storage, prevents microbial infection, and is desirable for development of good scale color. However the grain farmers met during the course of this project claimed to store their grains in rhumbu, both show the amount of vegetables (essentially tomatoes and onions) been stored by the farmers that were interviewed during the course of this research work. From the result, it glaringly shows that little of what they produced is been stored against off-season period when these items are now very costly in the market. The tomato farmers have no means of storing fresh tomatoes while the onion farmers use improper means to store the crop. The farmers thus store little compare to what they produced. It was also discovered that onions stores for a reasonably long period of time if the right type, well matured and whole onion is use for storage and the right storage structure and conditions are met. The period of storage ranges between four months to one year. In a good well ventilated store with good cultivars onion will store favorably for one year. The main problem usually encounter in onion storage is moldiness and rottenness where there is high moisture content in the stored onion, the temperature of the store is too high, poor ventilation as in the case of overcrowding or the onions were not properly cured before storage This can be overcome by curing the onions properly before storing and also by storing onions in stores that has the necessary requirements for onion storage. Other sources of problem during storage are insect infestation and rodent attack. 


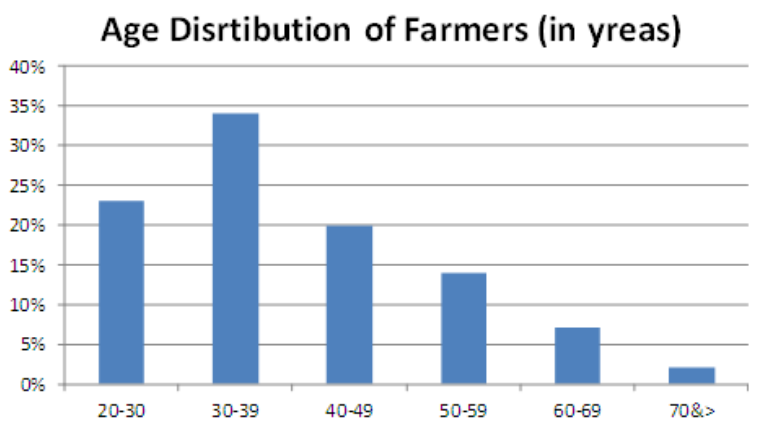

Fig.l Age Distribution of farmers (in years)

\section{Type of Farm Practise}

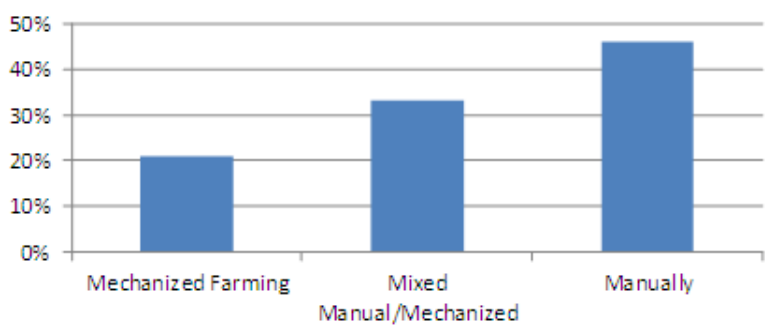

Fig.2: types of farm practice

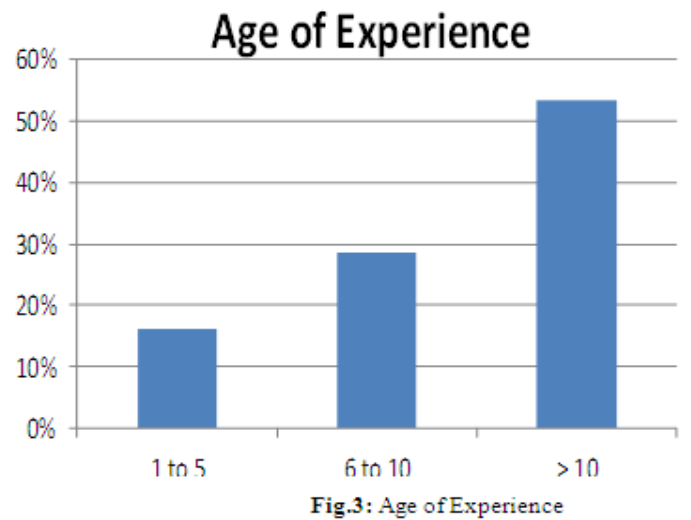

Crops Produced by the Farmer

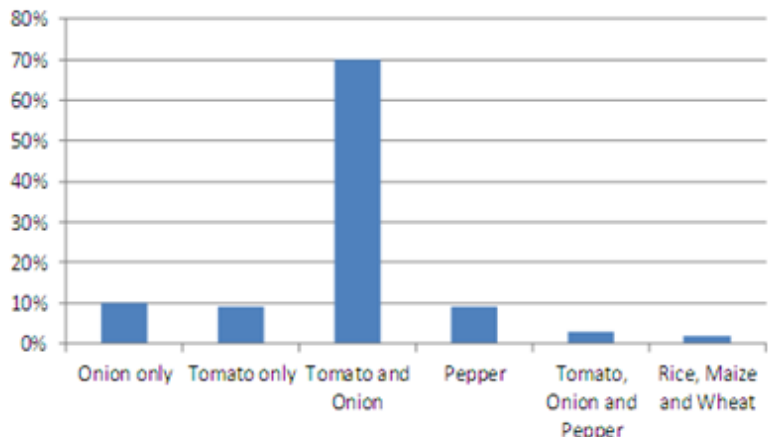

Fig.4: crops produced by farmers 


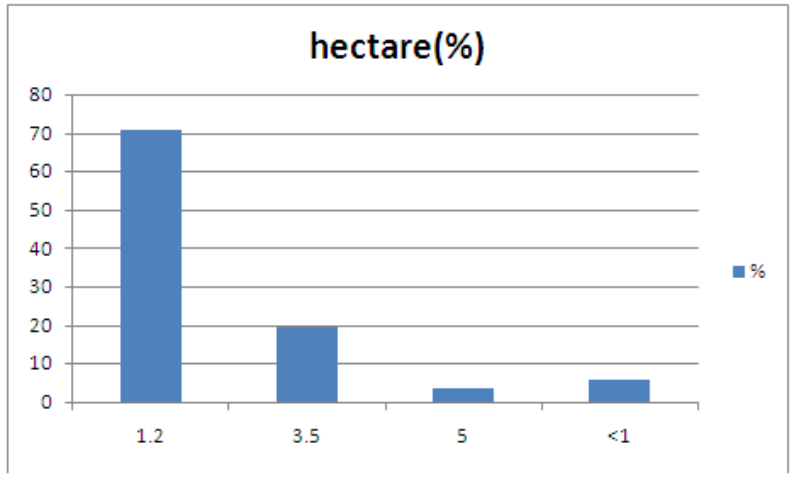

Fig. 5: Hectares in percentage of farmer

Type of Scale

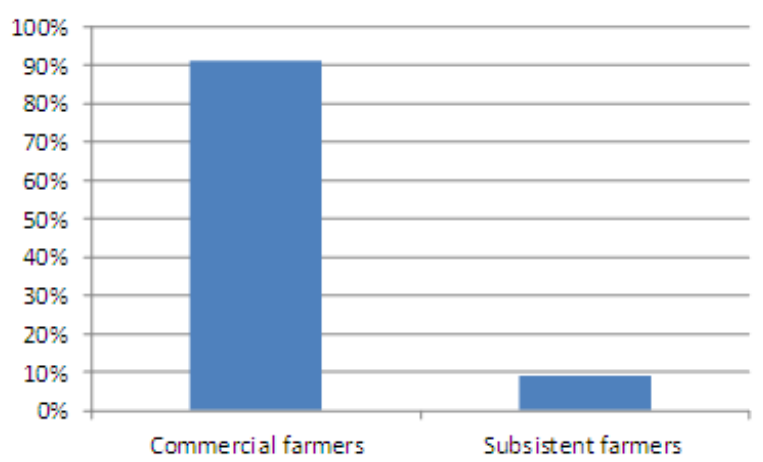

Fig.6: Type of farmers
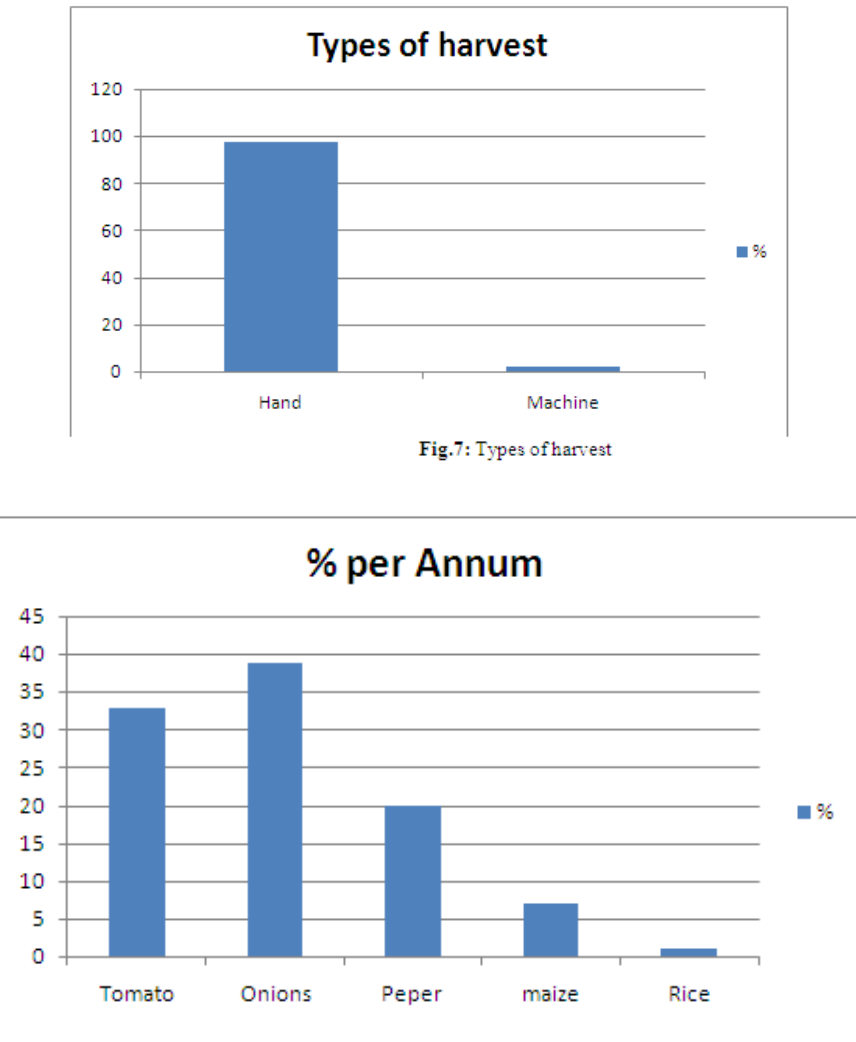

Fig 8: $\%$ Grown per annum 


\section{Stages of Harvest}

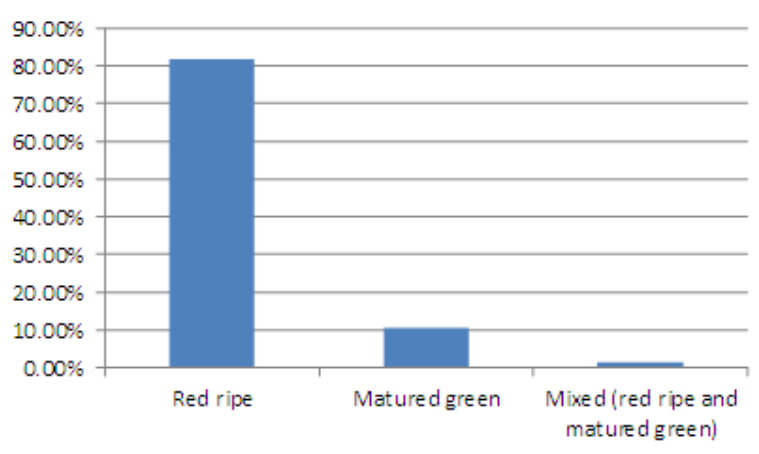

Fig.9: Stages of harvest
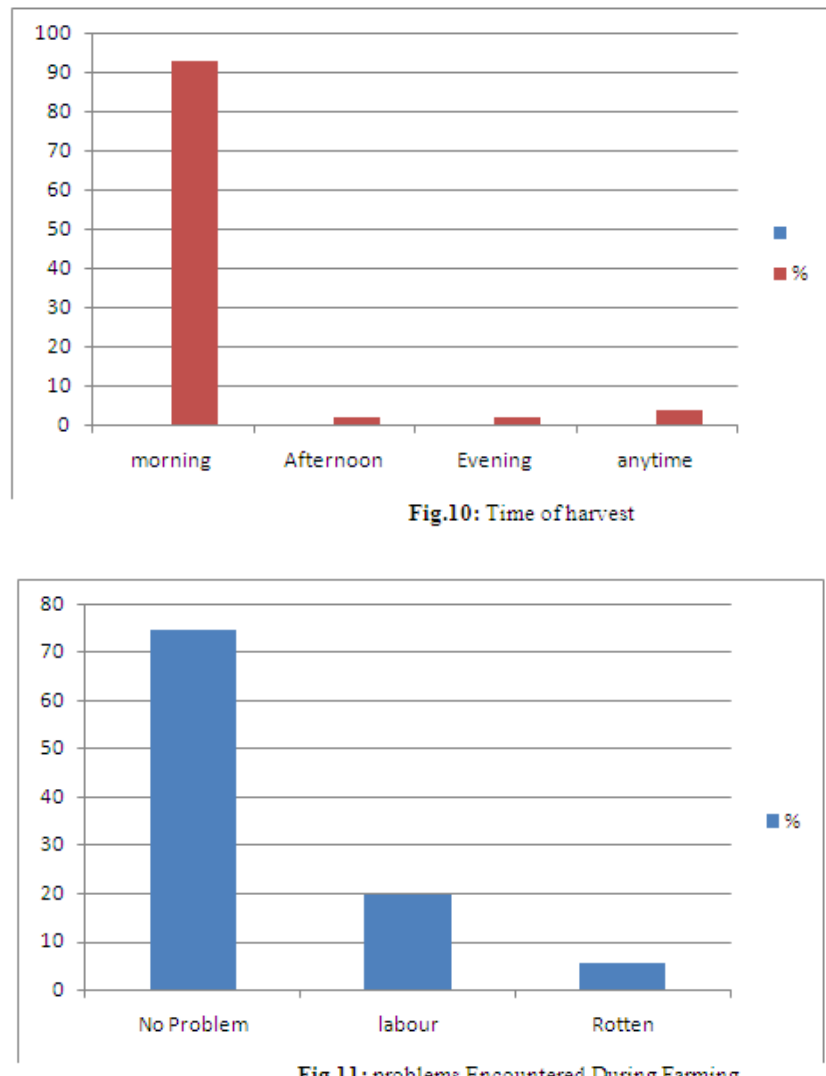

Fig.11: problems Encountered During Farming

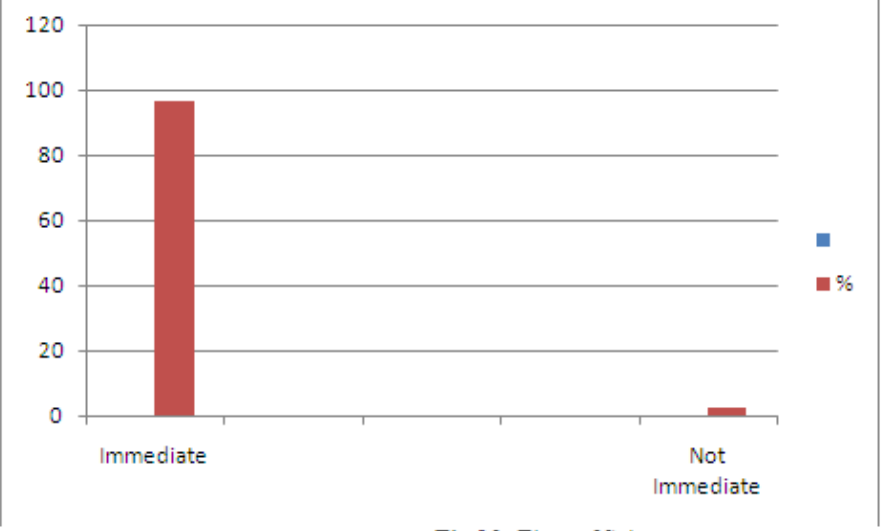

Fig.12: Time of Sales 

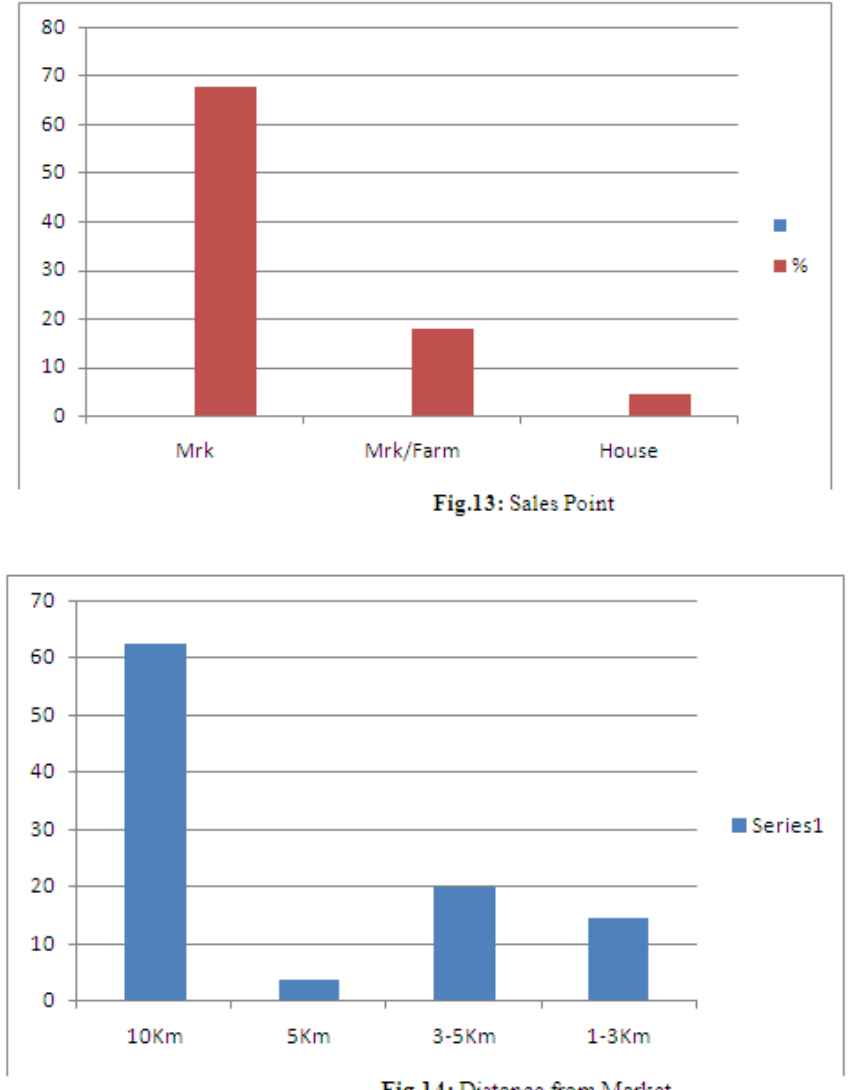

Fig.14: Distance from Market

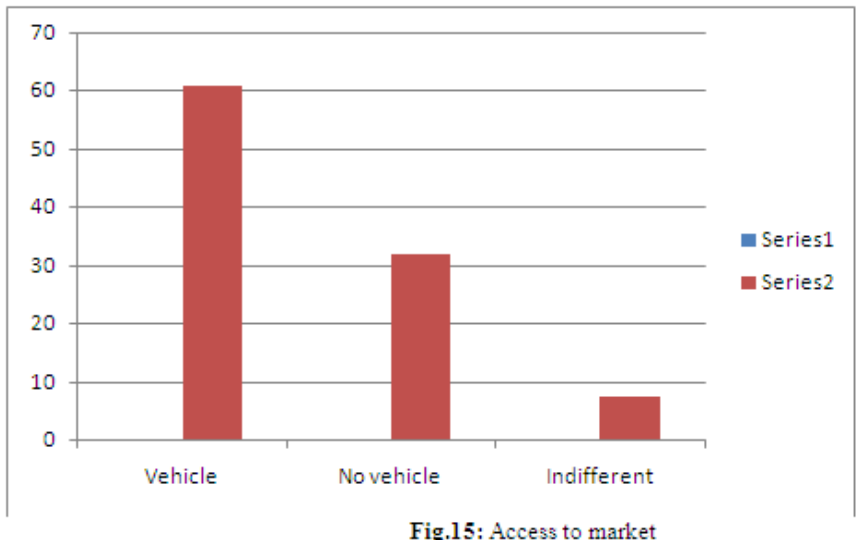

Fig.15: Access to market

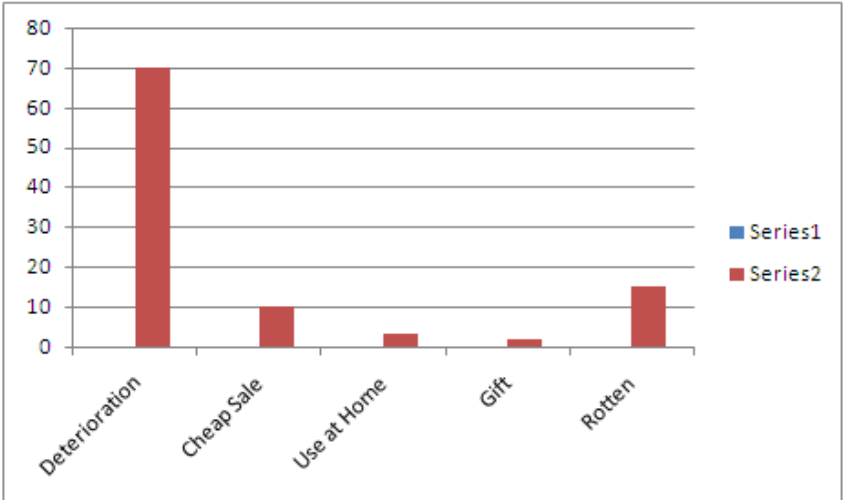

Fig.16: Lack of preservation and storage for tomatoes 


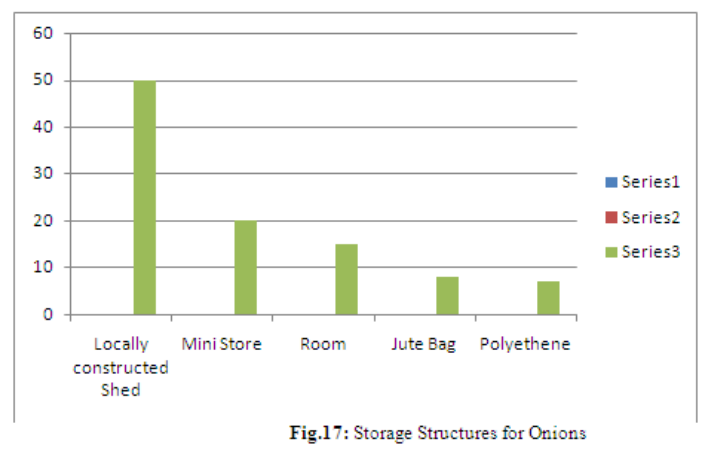

\section{Conclusion and Recommendations}

\section{Conclusion}

The results of the study indicated that the farmers in the study area experienced serious postharvest losses particularly due to poor post harvest handling measures. Improvement of these age-old practices and development of new technologies through organized research efforts have become necessary to prevent huge post-harvest losses of fruits and vegetables crops with a view to meeting the demand for food. However, there is an immediate and pressing need for more and improved Harvesting, transportation, processing, storage and handling facilities and improved marketing structure on farm produce and more concern for the needs of the small and medium size farmer.

\section{Recommendations}

As a result of the analysis from the survey, we hereby recommend the following;

- Extension activities of ADPs need to be intensified in these zones especially A and C to create more awareness on the storage needs for agricultural produce

- Training programmes should be held in each community to achieve a more result oriented training at the grassroots

- Technologies which have been developed by some Agricultural Research Institutes like Nigerian Stored

Products Research Institute (NSPRI) should be adopted to check these losses.

\section{References}

[1]. Dr.Jeanne Decuyperes Nutrient Charts: health alternatives (2000).Team copyright@ $2002-2014$

[2]. Harvard School of Public Health. Home and Garden information center: http;//hgic.Clemson.edu.

[3]. Smith, A. F. (1994). The Tomatoes in America, University of Ilorin Press.

[4]. Edward, R. Farnsworth: Handbook of fermented functional foods. CRC press. Horticulture 123: VI African Symposium on Horticultural Crops.

[5]. Tindal, H.D. and Proctor, F.J. (1980). Loss Prevention of Horticultural Crops in the Tropics. Prog. Fd. Nat. Sci., vol.4, Nos.3-4, pp. 25-39.

[6]. Okanlawon, Suleiman O. Relevant crop storage technologies for North-East Zone. A paper presented at the North-East Farming System Research and Extension Workshop $8^{\text {th }}-10^{\text {th }}$ March.1999 at Lake Chad Research Institute, Maiduguri.

[7]. Climatologically Information for Kano, Nigeria, Hongkong Observatory. Retrieved October 2012

[8]. Anazodo, U.G.N., T.O. Abimbola and J.A. Dairo (1986). Agricultural machinery inventory: Type and condition in Nigeria. A National Investigative Survey Report, Federal Department of Agriculture, Federal Ministry of Agriculture and Natural Resources, Lagos, Nigeria.

[9]. Krueger, R.A.(1988) Focus Groups : A Practical Guide for Applied Research. Thousand Oaks, CA; Sage

[10]. Lale, N.E.S. and Okunade, S.O. (1998). A survey of some aspects of fish processing in the Lake Chad District of Nigeria. Annals of Bornu 13/14 (1996-97). Pp.362-368.

[11]. Olayemi F. F. ., Adegbola J. A., Bamishaiye E. I. and Daura A. M. (2010).Assessment of Post Harvest Challenges of Small Scale Farm Holders of Tomatoes, Bell and Hot pepper in some Local Government Areas of Kano State, Nigeria Bayero Journal of Pure and Applied Sciences, 3(2): $39-42$

[12]. Agboola, S. D. (1980): The role of the Nigerian Stored Products Research Institute in Nigeria March towards self sufficiency in food. NSPRI occasional paper series No. 117 page 25-29

[13]. Ibrahim H.Y (2011) Optimal Farm Plan For Vegetable Production under Fadama in North Central Nigeria .Trakia Journal of Sciences, Vol. 9, No 4, pp 43-49, 2011

[14]. Muhammad, R.H., G.C.IHionu and F.F. Olayemi (2012).Assessment of the post harvest Knowledge of fruits and vegetable farmers in Garun Mallam L.G.A of Kano, Nigeria.Vol. 1 No 2, Pp 510-515

[15]. Mary, P (1997): Sustainable Practices for Vegetable Production in the South, NCSU. Southern Region. American Society of Horticulture science Blue-Ribson extension publication. Page 1-7.

[16]. Singh, A.; and Singh, Y.( 1992). Effect of vibration during transportation on the quality of tomatoes. J. Agric. Mech. Asia, Africa and Latin America. AMA 23: 70-72.

[17]. Further information on transport refers to FAO Diversification booklet No.10, 'Rural transport and traction enterprises for improved livelihoods

[18]. Janet, B and E. Richard (2000): Postharvest handling of fruits and vegetables. An Appropriate Technology Transfer for Rural Areas (ATTTRA) Horticulture Technical note. Page 1-19

[19]. Eke, H.N. (2010). The Perspective of E-Learning and Libraries in Africa: Challenges and Opportunities. Emerald Library Review, Vol. 59, Issue 4, 2010. p. 274-290. 